\title{
Studies on Growth, Yield and Economics of Lentil (Lens culinaris Medikus) var. IPL 316 as Influenced by Bioregulator and Micro Nutrient
}

\author{
Pavan Ganesh*, Vikram Singh, Dhananjay Tiwari and Dhanush Reddy \\ Department of Agronomy, Sam Higginbottom University of Agriculture, Technology and \\ Sciences, Prayagraj, Uttar Pradesh, India \\ *Corresponding author
}

A B S T R A C T

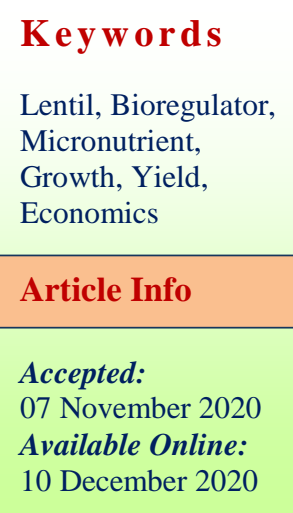

\section{Keywords}

Lentil, Bioregulator, Micronutrient, Growth, Yield, 10 December 2020
A field experiment was conducted during Rabi season of 2019, at crop research farm of Department of Agronomy at Sam Higginbottom University of Agriculture, Technology and Sciences, Prayagraj in North Eastern plains of Eastern Uttar Pradesh with the objective to study the effect of foliar feeding of bioregulator and micronutrient on growth, yield and economics of lentil (Lens culinaris Medikus) Var. IPL 316 under Randomized block design comprising of 10 treatments of which control $\left(\mathrm{T}_{1}\right)(\mathrm{N}: \mathrm{P}: \mathrm{K}$ at $20: 40: 20 \mathrm{~kg} / \mathrm{ha})$ and rest of treatments $\left(\mathrm{T}_{2}-\mathrm{T}_{10}\right)$ with combination of bioregulator (Thiourea) along with micronutrient (Iron) which are replicated thrice. The experimental results revealed that application of $\mathrm{T}_{10}$ (Thiourea $1000 \mathrm{ppm}+$ Iron $100 \mathrm{ppm}$ ) has recorded highest plant height $(43.03 \mathrm{~cm})$, highest number of branches/plant (3.87), maximum dry matter accumulation/plant $(12.15 \mathrm{gm})$, number of pods/plant(81.93). The application of $\mathrm{T}_{10}$ (Thiourea $1000 \mathrm{ppm}+$ Iron $100 \mathrm{ppm}$ ) has recorded significantly Highest Benefit: Cost ratio (2.59) maximum seed yield (1.52 $\mathrm{t} \mathrm{ha}^{-1}$ ), gross return (Rs. 77,440 ha ${ }^{-1}$ ) and net return (Rs.555,890 ha-1).

\section{Introduction}

India is the largest pulse-growing country which accounts for nearly one-third of the total world area under pulses and one-fourth of the total world production. India stands second in production of lentil after Canada. The major lentil-growing countries of the world include India, Canada, Turkey, Bangladesh, Iran, China, Nepal and Syria. Lentil occupies 1469 thousand ha area with the production of 1035 metric tons and a productivity level of $705 \mathrm{~kg}$ per hectare in India.
Lentil is the third most important pulse crop of North India which is mainly grown as rain-fed crop in Uttar Pradesh, Uttarakhand, Madhya Pradesh, Jharkhand, Bihar and West Bengal. Lentil plays key role in the diet of developing world. Lentils have the second highest ratio of protein per calorie of any legume, after soybean. Lentil provide a variety of essential nutrients to a person's diet, containing high levels of protein (20-30\%), minerals (2-5\%), vitamin B9.Lentil is typically rich in micronutrients and has the potential to provide adequate dietary amounts, especially for iron (Fe), zinc ( $\mathrm{Zn})$, and selenium (Se). 
Thiourea is a nitrogen and sulphur containing compound with better water solubility and absorption potential. Thiourea is a potential Bioregulator for alleviating Abiotic stress. Structurally, Thiourea molecule has two main functional groups; 'thiol' is reported vital for oxidative stress response and 'imino' strikingly capable to fulfil the increased $\mathrm{N}$ requirement under abiotic stress conditions. Thiols are well-known to maintain the disturbed redox state (-SH/-S-S- ratio) of the cell and its proper functioning under stress conditions (Nathawat et al., 2007 and Dhikwal et al., 2012). Its involvement and applicability have also been demonstrated for increasing grain filling under drought. At physiological level, this is directly associated with enhanced photosynthesis, increased metabolite translocation and co-ordinated regulation of plant's source to sink relationships (Pandey et al., 2013).

The deficiency of iron in plants causes significant changes in the plant metabolism and also induces chlorosis, especially in young leaves and leads to very low reutilization. Iron enters in many plant enzymes that play dominant roles in oxidation- reduction reactions of photosynthesis and respiration. Iron participates in content of many enzymes: cytochromes, ferredoxine, superoxide dismutase.

\section{Materials and Methods}

A field experiment was conducted during rabi season of 2019, at Crop research farm of Department of Agronomy at Sam Higginbottom University of Agriculture, Technology, and Sciences, Prayagraj which is located at $25^{\circ} 24^{\prime} 42^{\prime \prime} \mathrm{N}$ latitude, $81^{\circ} 50^{\prime} 56^{\prime \prime} \mathrm{E}$ longitude and $98 \mathrm{~m}$ altitude above the mean sea level (MSL). To assess the effect of bioregulator and micronutrient on growth and yield of lentil (Lens culinaris Medikus). The experiment was laid out in Randomized Block Design comprising of 10 treatments which are replicated thrice. Each treatment net plot size is $3 \mathrm{~m} \times 3 \mathrm{~m}$. First treatment $\left(\mathrm{T}_{1}\right)$ is categorized as control $20 \mathrm{~kg} \mathrm{~N}^{-1}$ through urea and DAP, $40 \mathrm{~kg} \mathrm{ha}^{-1} \mathrm{P}_{2} \mathrm{O}_{5}$ through DAP and $20 \mathrm{~kg} \mathrm{ha}^{-1}$ $\mathrm{K}_{2} \mathrm{O}$ through Muriate of Potash. Rest of the treatments applied with recommended dose of fertilizers (RDF) $20 \mathrm{~kg} \mathrm{ha}^{-1}$ through urea and DAP, $40 \mathrm{~kg} \mathrm{ha}^{-1}$ through DAP and $20 \mathrm{kgha}^{-1}$ through Muriate of Potash in addition with bioregulator like Thiourea and micronutrient like Iron when applied in combinations as follows, $\left(\mathrm{T}_{2}\right)$ Thiourea $500 \mathrm{ppm}+$ Iron 50 ppm, $\left(\mathrm{T}_{3}\right)$ Thiourea $500 \mathrm{ppm}+$ Iron $75 \mathrm{ppm}$, $\left(\mathrm{T}_{4}\right)$ Thiourea $500 \mathrm{ppm}+$ Iron $100 \mathrm{ppm},\left(\mathrm{T}_{5}\right)$ Thiourea $750 \mathrm{ppm}+$ Iron $50 \mathrm{ppm},\left(\mathrm{T}_{6}\right)$ Thiourea $750 \mathrm{ppm}+$ Iron $75 \mathrm{ppm},\left(\mathrm{T}_{7}\right)$ Thiourea $750 \mathrm{ppm}+$ Iron $100 \mathrm{ppm},\left(\mathrm{T}_{8}\right)$ Thiourea $1000 \mathrm{ppm}+$ Iron $50 \mathrm{ppm},\left(\mathrm{T}_{9}\right)$ Thiourea $1000 \mathrm{ppm}+$ Iron $75 \mathrm{ppm},\left(\mathrm{T}_{10}\right)$ Thiourea $1000 \mathrm{ppm}+$ Iron 100 ppm. Foliar application of Thiourea and Iron was done by mixing them with water and is sprayed during Flower initiation stage and at Pod formation stage. The lentil crop was harvested treatment wise at harvesting maturity stage. Growth parameters viz. plant height $(\mathrm{cm})$, number of branches, dry matter accumulation $g$ plant ${ }^{-1}$ were recorded manually on five randomly selected representative plants from each plot of each replication separately and after harvesting, seeds were separated from each net plot and were dried under sun for three days. Later winnowed, cleaned and seed yield per ha was computed and expressed in tonnes per hectare. After complete drying under sun for 10 days stover yield from each net plot was recorded and expressed in tonnes per hectare. The data was computed and analysed by following statistical method of Gomez and Gomez (1984). The benefit: cost ratio was worked out after price value of seed with straw and total cost included in crop cultivation. 


\section{Results and Discussion}

\section{Effect on growth parameters}

\section{Plant height}

It is evident from Table 1 that plant height measured increased with advancement in crop growth. At harvest the treatment $\mathrm{T}_{10}$ (Thiourea $1000 \mathrm{ppm}+$ Iron $100 \mathrm{ppm}$ ) recorded maximum height of $43.03 \mathrm{~cm}$. At harvesting stage maximum plant height was measured in $\mathrm{T}_{10}$ and treatments $\mathrm{T}_{8}$ and $\mathrm{T}_{9}$ were found statistically at par to $\mathrm{T}_{10}$. The highest plant height in treatment $\mathrm{T}_{10}$ may be ascribed due to the continuous supply of nutrients throughout all growth stages with beneficial association between Thiourea and Iron along with chemical fertilizers. This positive changes in the crop might be due to better growth and development of crop with thiourea treatment action possibly targeted the meristematic activity of apical tissues with stimulatory effects on cell division which causes increase in shoot length and cell number for improved leaf area (mostly by increased Sulphur and nitrogen nutrition). According to Trivedi et al., (2011), The increase in the availability of iron to plant might have stimulated the metabolic and enzymatic activities thereby increasing the growth of the crop.

\section{Number of branches/plant}

At harvesting stage maximum number of branches (3.87) are produced by $\mathrm{T}_{10}$ (Thiourea $1000 \mathrm{ppm}+$ Iron $100 \mathrm{ppm}$ ) and $\mathrm{T}_{9}$ is statistically at par to maximum. The maximum number of branches per plant was attained under the treatment because thiourea increased the net photosynthetic rates and the concentrations of total chlorophyll and starch in the leaves. Similar findings also observed by Yadav (2002).

\section{Dry matter accumulation}

The treatment $\mathrm{T}_{10}$ (Thiourea $1000 \mathrm{ppm}+$ Iron $100 \mathrm{ppm})$ recorded maximum dry matter accumulation of $12.15(\mathrm{~g})$ at the harvesting stage and $\mathrm{T}_{8}, \mathrm{~T}_{9}$ treatments are found statistically at par to maximum dry matter accumulation. This might be due to its role in starch formation and protein synthesis as well as maintenance and synthesis of chlorophyll in plants. The increase in the availability of iron to plant might have stimulated the metabolic and enzymatic activities thereby increasing the growth of the crop Trivedi et al., (2011)

\section{Yield and yield attributes}

\section{Number of pods/plant}

Significant effect was observed by the statistical analysis of number of pods per plant. Treatment Thiourea $1000 \mathrm{ppm}+100$ ppm Fe recorded significant and highest number of pods per plant (81.07). However, Thiourea $1000 \mathrm{ppm}+50 \mathrm{ppm} \mathrm{Fe}$ and Thiourea $1000 \mathrm{ppm}+75 \mathrm{ppm}$ Fe recorded statistical parity with Thiourea $1000 \mathrm{ppm}+$ $100 \mathrm{ppm} \mathrm{Fe}$. This might be attributed to triggered nitrogen metabolism of crop and extended retention of moisture by the treated crop especially during moisture stress period, which might have helped to bear a greater number of pods per plant at harvest. These results are in conformity with the findings of Singh, R.P. and Dasharath Singh (2017) illustrating advantage of foliar application for incremental yield enhanced in pulses.

\section{Seed yield}

Seed yield was significantly influenced with different combinations of thiourea and iron with chemical fertilizers. The maximum yield $\left(1.52 \mathrm{t} \mathrm{ha}^{-1}\right)$ was observed with $\mathrm{T}_{10}$ (Thiourea $1000 \mathrm{ppm}+$ Iron 100 ppm) (Table 2). 
Table.1 Effect of Thiourea and Iron on growth parameters of lentil var. 'IPL 316' at harvest

\begin{tabular}{|c|c|c|c|c|c|}
\hline S.No & T.No. & Treatments & Plant height (cm) & $\begin{array}{l}\text { No. ofbranches } \\
\text { plant }^{-1}\end{array}$ & $\begin{array}{c}\text { Dry matter } \\
\text { accumulation }\left(\mathrm{g} \text { plant }^{-1}\right)\end{array}$ \\
\hline 1 & $\mathrm{~T}_{1}$ & Control & 32.04 & 3.00 & 11.22 \\
\hline 2 & $\mathrm{~T}_{2}$ & Thiourea 500 ppm + Iron 50 ppm & 34.73 & 2.93 & 11.58 \\
\hline 3 & $\mathrm{~T}_{3}$ & Thiourea $500 \mathrm{ppm}+$ Iron $75 \mathrm{ppm}$ & 34.97 & 2.93 & 11.62 \\
\hline 4 & $\mathrm{~T}_{4}$ & Thiourea $500 \mathrm{ppm}+$ Iron $100 \mathrm{ppm}$ & 35.33 & 3.00 & 11.63 \\
\hline 5 & $\mathrm{~T}_{5}$ & Thiourea 750 ppm + Iron 50 ppm & 35.49 & 2.93 & 11.82 \\
\hline 6 & $\mathrm{~T}_{6}$ & Thiourea 750 ppm + Iron 75 ppm & 35.68 & 3.00 & 11.83 \\
\hline 7 & $\mathrm{~T}_{7}$ & Thiourea $750 \mathrm{ppm}+$ Iron $100 \mathrm{ppm}$ & 36.33 & 3.07 & 11.84 \\
\hline 8 & $\mathrm{~T}_{8}$ & Thiourea $1000 \mathrm{ppm}+$ Iron $50 \mathrm{ppm}$ & 40.70 & 3.20 & 12.11 \\
\hline 9 & $\mathrm{~T}_{9}$ & Thiourea 1000 ppm + Iron 75 ppm & 42.17 & 3.53 & 12.12 \\
\hline \multirow[t]{3}{*}{10} & $\mathrm{~T}_{10}$ & Thiourea $1000 \mathrm{ppm}+$ Iron $100 \mathrm{ppm}$ & 43.03 & 3.87 & 12.15 \\
\hline & & $\operatorname{SEm}( \pm)$ & 0.88 & 0.14 & 0.01 \\
\hline & & $\mathrm{CD}(\mathrm{P} 0.05)$ & 2.60 & 0.41 & 0.04 \\
\hline
\end{tabular}

Table.2 Effect of Thiourea and Iron on yield and yield attributing characters of lentil var. 'IPL 316'

\begin{tabular}{|c|c|c|c|c|c|}
\hline S. No & T. No & Treatments & No. of pods plant ${ }^{-1}$ & $\begin{array}{l}\text { Seed Yield } \\
\left(t \mathbf{h a}^{-1}\right)\end{array}$ & $\begin{array}{c}\text { Stover Yield } \\
\quad\left(\mathrm{t} \mathrm{ha}^{-1}\right)\end{array}$ \\
\hline 1 & $\mathrm{~T}_{1}$ & Control & 60.87 & 0.90 & 1.87 \\
\hline 2 & $\mathrm{~T}_{2}$ & Thiourea 500 ppm + Iron 50 ppm & 68.40 & 1.05 & 2.07 \\
\hline 3 & $\mathrm{~T}_{3}$ & Thiourea $500 \mathrm{ppm}+$ Iron $75 \mathrm{ppm}$ & 69.20 & 1.12 & 2.21 \\
\hline 4 & $\mathrm{~T}_{4}$ & Thiourea $500 \mathrm{ppm}+$ Iron $100 \mathrm{ppm}$ & 70.27 & 1.16 & 2.29 \\
\hline 5 & $\mathrm{~T}_{5}$ & Thiourea $750 \mathrm{ppm}+$ Iron $50 \mathrm{ppm}$ & 74.20 & 1.22 & 2.40 \\
\hline 6 & $\mathrm{~T}_{6}$ & Thiourea 750 ppm + Iron 75 ppm & 75.33 & 1.29 & 2.52 \\
\hline 7 & $\mathrm{~T}_{7}$ & Thiourea $750 \mathrm{ppm}+$ Iron $100 \mathrm{ppm}$ & 76.33 & 1.33 & 2.58 \\
\hline 8 & $\mathrm{~T}_{8}$ & Thiourea $1000 \mathrm{ppm}+$ Iron $50 \mathrm{ppm}$ & 80.20 & 1.46 & 2.79 \\
\hline 9 & $\mathrm{~T}_{9}$ & Thiourea $1000 \mathrm{ppm}+$ Iron 75 ppm & 81.13 & 1.47 & 2.80 \\
\hline \multirow[t]{3}{*}{10} & $\mathrm{~T}_{10}$ & Thiourea $1000 \mathrm{ppm}+$ Iron 100 ppm & 81.93 & 1.52 & 2.85 \\
\hline & & $\operatorname{SEm}( \pm)$ & 0.98 & 0.02 & 0.02 \\
\hline & & $\mathrm{CD}(\mathrm{P} 0.05)$ & 2.91 & 0.06 & 0.07 \\
\hline
\end{tabular}


Table.3 Effect of Thiourea and Iron on economics of lentil var. 'IPL 316'

\begin{tabular}{|c|c|c|c|c|c|c|}
\hline S.No & T.No. & Treatments & $\begin{array}{c}\text { Cost of } \\
\text { cultivation }^{\#} \\
\left(\mathbf{x} 10^{3} \text { Rs.ha }^{-1}\right)\end{array}$ & $\begin{array}{c}\text { Gross return } \\
\left(\times \text { 10 }^{3}\right. \\
\left.\text { Rs.ha }^{-1}\right)\end{array}$ & $\begin{array}{l}\text { Net return } \\
\left(\begin{array}{l}\mathbf{x} \mathbf{1 0}^{3} \\
\left.\text { Rs.ha }^{-1}\right)\end{array}\right.\end{array}$ & $\begin{array}{l}\text { Benefit: } \\
\text { Cost ratio }\end{array}$ \\
\hline 1 & $\mathrm{~T}_{1}$ & Farmers practice & 21.43 & 46.07 & 24.64 & 1.15 \\
\hline 2 & $\mathrm{~T}_{2}$ & $\begin{array}{l}\text { Thiourea } 500 \mathrm{ppm}+\text { Iron } 50 \\
\text { ppm }\end{array}$ & 21.49 & 53.40 & 31.91 & 1.48 \\
\hline 3 & $\mathrm{~T}_{3}$ & $\begin{array}{l}\text { Thiourea } 500 \mathrm{ppm}+\text { Iron } 75 \\
\text { ppm }\end{array}$ & 21.49 & 57.02 & 35.53 & 1.65 \\
\hline 4 & $\mathrm{~T}_{4}$ & $\begin{array}{l}\text { Thiourea } 500 \text { ppm + Iron } 100 \\
\text { ppm }\end{array}$ & 21.49 & 59.02 & 37.52 & 1.75 \\
\hline 5 & $\mathrm{~T}_{5}$ & $\begin{array}{l}\text { Thiourea } 750 \mathrm{ppm}+\text { Iron } 50 \\
\text { ppm }\end{array}$ & 21.53 & 62.35 & 40.83 & 1.90 \\
\hline 6 & $\mathrm{~T}_{6}$ & $\begin{array}{l}\text { Thiourea } 750 \mathrm{ppm}+\text { Iron } 75 \\
\text { ppm }\end{array}$ & 21.53 & 65.80 & 44.27 & 2.06 \\
\hline 7 & $\mathrm{~T}_{7}$ & $\begin{array}{l}\text { Thiourea } 750 \mathrm{ppm}+\text { Iron } 100 \\
\text { ppm }\end{array}$ & 21.53 & 67.78 & 46.25 & 2.15 \\
\hline 8 & $\mathrm{~T}_{8}$ & $\begin{array}{l}\text { Thiourea } 1000 \mathrm{ppm}+\text { Iron } 50 \\
\text { ppm }\end{array}$ & 21.56 & 74.55 & 52.99 & 2.46 \\
\hline 9 & $\mathrm{~T}_{9}$ & $\begin{array}{l}\text { Thiourea } 1000 \mathrm{ppm}+\text { Iron } 75 \\
\text { ppm }\end{array}$ & 21.56 & 75.00 & 53.44 & 2.48 \\
\hline 10 & $\mathrm{~T}_{10}$ & $\begin{array}{l}\text { Thiourea } 1000 \mathrm{ppm}+\text { Iron } 100 \\
\text { ppm }\end{array}$ & 21.56 & 77.44 & 55.89 & 2.59 \\
\hline
\end{tabular}

\#Data not subjected to statistical analysis

The effect of Thiourea and Iron had significant influence on seed yield at production increased over farmer practices $\left(\mathrm{T}_{1}\right)$ when compared with treatment $\mathrm{T}_{10}$ (Thiourea $1000 \mathrm{ppm}+$ Iron 100 ppm).Treatments $\mathrm{T}_{8}$ and $\mathrm{T}_{9}$ were found statistically at par to maximum $\left(\mathrm{T}_{10}\right)$.The increase in the yield recorded in this investigation could be a reflection of the effect of thiourea on growth and development.

The yield was higher due to increase in the number of branches per plant pods and hence more seeds, which could lead to increase in photosynthesis, resulting in greater transfer of as similates to the seeds and causing increase in their weight. These results are conformity with Anitha et al., (2005), Anitha et al., (2006). The application of iron sulphate plays an important role in synthesis of chlorophyll and plant growth regulator. Iron also improves photosynthesis and assimilates transportation to sinks and finally increases seed and stover yield. This may include increase in carbohydrate synthesis. Similar effect of foliar spray of iron was observed in cowpea by Anitha et al., (2005).

\section{Stover yield}

The application of Thiourea and Iron had also significantly influenced the stover production of the lentil crop. $\mathrm{T}_{10}$ (Thiourea $1000 \mathrm{ppm}+$ Iron $100 \mathrm{ppm}$ ) gained maximum stover yield and treatments $\mathrm{T}_{8}$ and $\mathrm{T}_{9}$ were found statistically at par to maximum. Stover yield also exhibited similar trend as that of seed yield of lentil. The increase in seed and stover yield due to thiourea application is a clear reflection of increase in growth and yield 
attributes as the thiourea helps in better dry matter partitioning, increase net photosynthesis and nitrate reductase activity. These results are in close conformity with the results of Sharma et al., (2002), Shekhawat et al., (2003), Anitha et al., (2006). $\mathrm{T}_{10}$ (Thiourea $1000 \mathrm{ppm}+$ Iron $100 \mathrm{ppm}$ ) recorded maximum number of pods per plant with $\mathrm{T}_{8}$, and $\mathrm{T}_{9}$ are at par to $\mathrm{T}_{10}$. This might be attributed to triggered nitrogen metabolism of crop and extended retention of moisture by the treated crop especially during moisture stress period, which might have helped to bear a greater number of pods per plant at harvest.

The application of iron significantly increased the yield characteristics in lentil. The yield of crop is the cumulative effect of growth attributing characters and yield characters such as pods per plant. These findings are in confirmation to the earlier reported by Kumar et al., (2009) and Khan et al., (2014).

\section{Economics}

Among the different combination of nutrient source highest gross return (Rs.77,440 ha ${ }^{-1}$ ), maximum net return (Rs.55,890 ha ${ }^{-1}$ ) and Higher benefit cost ratio (2.59)recorded by $\left(\mathrm{T}_{10}\right)$ Thiourea $1000 \mathrm{ppm}+$ Iron 100 ppm.

In conclusion the treatment Thiourea 1000 $\mathrm{ppm}+100 \mathrm{ppm} \mathrm{Fe}$ recorded highest seed yield (1.52 t/ha) and gross return $\left(77.44 \times 10^{3}\right.$ Rs./ha). However, highest net return $(55.89 \times$ $10^{3} \mathrm{Rs} . / \mathrm{ha}$ ) and benefit: cost ratio (2.59) was observed under Thiourea 1000 ppm + 100 ppm Fe which may be more preferable for farmers since it is economically more profitable and also achieved statistical parity with Thiourea $1000 \mathrm{ppm}+50 \mathrm{ppm} \mathrm{Fe}$, Thiourea $1000 \mathrm{ppm}+75$ ppm Fe regarding seed yield of lentil var. 'IPL 316' and hence, can be recommended to the farmers (Table 3 ).

\section{Acknowledgements}

I express my gratitude to my advisor Dr.Vikram Singh for constant support, guidance and for his valuable suggestions for improving the quality of this work. I am indebted to Prof. (Dr.) Thomas Abraham who has been a constant source of inspiration and all the faculty members of Department of Agronomy, SHUATS, Prayagraj, Uttar Pradesh (U.P), India for providing necessary facilities, for their cooperation, encouragement and support.

\section{References}

Anitha S, Sreenivan E and Purushothaman S M (2005) Response of cowpea (Vigna ungiculata L. Walp) to foliar nutrition of zinc and iron in the oxisols of Kerala. Legume Res 28:294-96.

Anitha, S.; Purushothaman, S. M. and Sreenivasan, E. 2006. Response of horse gram (Macrotyloma uniflorum L. Verdc) to thiourea application under rainfed conditions. Leg.Res. 29(2):146-149.

Balachandar D, Nagarajan P and Gunasekaran S (2003) Effect of organic amendments and micronutrients on nodulation and yield of blackgram in acid soil. Legume Res 26:192-95.

Bansal, R. L. and Chahal, D. S. 1990. Interactive effect of $\mathrm{Fe}$ and $\mathrm{Mn}$ on growth and nutrient content of moong (Vigna radiata). Acta AgronomicaHungarica39: 59-63.

Bhadoria, R.B.S., Kushwaha, H.S. and Jadaun, R.S. 2002. Effect of thiourea on yield and economics of cowpea (Vigna unguiculata) under rainfed conditions. Extended Summaries Vol. 1: 2nd International Agronomy Congress 26-30 November 2002, IARI, New Delhi, pp.453-453.

Burman, U., Garg, B.K., Kathju, S. (2000). Influence of thiourea on photosynthesis, Nitrogen metabolism and yield of clusterbean [Cyamopsis tetragonoloba (L.) Taub]. Plant growth Regulation, 48(3)237245. 
Choudhary, R.P., Sharma, S.K. and Dahama, A.K. 2003. Yield components of greengram [Vigna radiata (L.)] as influenced by phosphorus and thiourea. Annals of Agricultural Research, 24 (1):203-204.

Darwesh D A (2011) Effect of soil and foliar application of iron chelate on nutrient balance in lentil (Lens esculenta L.) by using modified dris equation. Mesopotamia J Agric., 39:39-51.

Dhikwal, S.R., Kumawat, S.M., Das, S and Jat, B.L. (2012). Effect of bio-regulators application on productivity of barley (Hordeum vulgare L.) in arid conditions of western Rajasthan. Forage Res., 38(2): 106-111.

Fasaei G R, Ronaghi A, Maftoun M, Karimian N and Soltanpour P N (2005) Ironmanganese interaction in chickpea as affected by foliar and soil application of iron in a calcareous soil. Commun Soil Sci pl Anal 36: 1717-25.

Garg, B.K., Burman, U. and Kathju, S. 2006. Influence of thiourea on photosynthesis, nitrogen metabolism and yield of clusterbean [Cyamopsis tetragonoloba $(\mathrm{L}$. Taub.] under rainfed condition of Indian arid zone. Plant Growth Regulation 48 (3): 237- 245

Gawad A A, Hariri D M, Shetaia A M A and Bahr AA (1991) Yield and yield components responses of chickpea (Cicer arietinum L.) to phosphorus fertilization and micronutrients. Afr J Agric Sci 18:6171.

Geeta Roat, Dadheech R.C., Solanki N.S. and Sumeriya H.K. 2008. Effect of phosphorus, sulphur and thiourea on growth, yield attributes and yield of clusterbean [Cymopsis tetragonoloba (L.) Taub.]. Haryana Journal of Agronomy 24(1/2): 92-94.

Ghandali V V and DehsorkhiA N (2017) Investigation of foliar application of Zinc and Iron elements in nano form on growth and yield of cowpea under water deficit stress. J Appl Res Pl Ecophysiol, 4:109-36.

Ghanshyam and Pareek B.L., 2009. Effect of sulphur and thiourea on growth and yield of mothbean [Vigna aconitifoliaJacq. Marchal] in arid western Rajasthan. Annals of Biology 25 (1): 17-19.

Gohari, A. A. and Niyaki, A. N. 2010. Effects of iron and nitrogen fertilizers on yield and yield components of peanut (Arachis hypogaea L.) American Eurasian Journal of Agriculture \& Environment Science, 9(3): 256-262.

Gupta, P.K., Sharma, N.L., Acharya, H.K., Gupta, S.K. and Mali, G.C. 2003. Response of mungbean to zinc and iron on vertisols in south-eastern plains of Rajasthan. Advance in Arid Legume Research.13: 259-262.

Guruprasad, B. P., Kuligod, V. and Hundekar, S. T., 2009. Influence of methods of iron sulphate application on yield and nutrient uptake by ruling groundnut (Arachis hypogea $L$.) genotypes in calcareous soils. Karnataka J. Agric. Sci., 22(5): 11041106.

Janmohammadi M, Javanmard A and Sabaghnia $N$ (2012) Influences of micro-nutrients (zinc and iron) and bio-fertilizer on yield and yield components of chickpea (Cicer arietinum L.) Cultivars. Agric Forestry 57:53-66.

Khan, N., Tariq, M., Ullah, K., Muhammad, D., Khan, I., Rahatulaah, K., Ahmed, N. and Ahmed, S. 2014. Effect of molybdenum and iron on nodulation, nitrogen fixation and yield of chickpea genotypes (Cicer arietinum L.). Journal of Agriculture and Veterinary Science, 7(1):63-79.

Kuldeep, Kumawat P D and Chaudhary M (2017) Response of chickpea (Cicer arietinum L.) to iron and zinc nutrition on protein and chlorophyll content. Env Eco 35: 1894- 97.

Kumar V, Dwivedi V N and Tiwari D.D. (2009) Effect of phosphorus and iron on yield and mineral nutrition in chickpea. Ann Pl Soil Res, 11:16-18.

Kumari S, Dubey S K and Singh AK (2017) Effect of Iron Application and Rhizobium Inoculation on uptake of Nutrients in Grain and Stover of Chickpea (Cicer arietinum 
L.) Int J CurrMicrobiol App Sci 6:1437-43.

Kumpawat B S and Manohar S (1994) Effect of Rhizobium inoculation, phosphorus and micronutrients on nodulation and protein content of gram. Madras Agric J 81:63031.

Latif E A and Haggan M AE (2014) Effect of micronutrients foliar application on yield and quality traits of soybean cultivars. Int $J$ Agric Crop Sci 7:908-14. lentil (Lens esculenta L.) by using modified dris equation. Mesopotamia J Agric39:39-51.

Lourduraj, A. C., Christopher, Krishan, R. K. and Geethalakshmi, V.1997.Micro nutrient fertilization in groundnut. Madras Agricultural Journal, 843: 362-363.

Meena K K. and Meena R.S. 2013. Effect of sulphur and iron fertilization on growth parameters, yields and nutrient uptake of mungbean (Vigna radiata L.) in arid western Rajasthan. Environment and Ecology, 31 (1): 227-231.

Meena, B.S. and Sharma, D.D. 2005. Effect of phosphorus sources, solubilizers and bioregulators on growth, yield and $\mathrm{P}$ uptake by pigeonpea (Cajanus cajan). Indian Journal of Agronomy 50: 143- 145.

Mevada K D, Patel J J and Patel K P (2005) Effect of micronutrients on yield of urdbean.

Moosavi A A and Ronaghi A (2011) Influence of foliar and soil applications of iron and manganese on soybean dry matter yield and iron-manganese relationship in a calcareous soil. Australian J Crop Sci 5:1550-56.

Mundra, S. L. and Bhati, D. S. 1994. Effect of $\mathrm{Fe}, \mathrm{Mn}$ and Rhizobium inoculation on growth, nodulation $\mathrm{Fe}$ : $\mathrm{Mn}$ ratio and protein content of cowpea. Farming System, 10: 38-40.

Nathawat, N.S., Nair, J.S., Kumawat, S.M., Yadava, N.S., Singh, G., Ramaswamy, N.K., Sahu M.P. and D'souza, S.F. (2007). Effect of seed soaking with thiols on the antioxidant enzymes and photosystem activities in wheat subjected to water stress. Biol. Plant., 51: 93-97.

Pandey M, Srivastava Ak (2013). Thiourea a
ROS scavenger, regulates source to sink relationship for enhanced crop yield and oil content in Brassica juncea. Plos one 8(9): e73921.

Patel, J.S. 1991. Effect of elemental sulphur and foliar applied chemicals on growth, nutrition and productivity of gram (Cicer arietinum L.) grown on calcareous soil. Ph.D. Thesis, Rajasthan Agricultural University, Bikaner.

Pingoliya K K, Mathur A K, Dotaniya M L, Jajoria D K and Narolia G P (2014) Effect of phosphorus and iron levels on growth and yield attributes of chickpea (Cicer arietinum L.) under agroclimatic zone a of Rajasthan, India. Legume Res 37:537-41.

Ram, Punia, Tetrawal, Meena, Pratap and Chaudhary (2018). Effect of Hydrogel and foliar nutrition sprays on productivity and profitability of lentil under rainfed situation of south eastern plains zone of Rajasthan. International journal of Advanced Scientific Research and Management, 2455-6378.

Rao, J.S.P. 1998. Growth and mineral nutrient composition of six cultivars of green gram (Vigna radiata L.) growth at normal and deficient levels of iron supply. Madras Agricultural Journal, 85: 96-98.

Sadeghi S.M. and Noorhosseini S.A. 2014. Evaluation of foliar application effects of $\mathrm{Zn}$ and $\mathrm{Fe}$ on yield and its components of lentil (Lens culinaris). Indian Journal of Fundamental and Applied Life Sciences, 4(2): 220-225.

Saini A K and Singh R (2017) Effect of sulphur and iron fertilization on growth and yield of greengram (Vigna radiata L.). Int $J$ CurrMicrobiol App Sci 6:1922-29.

Sakal R, Singh P, Sinha R B and Bhogal M S (1996) Twentyfive years of research on micro and secondary nutrients in soils and crops of Bihar. Res Bull Agric, pp 1-207. Rajendra Agricultural University, Pusa, Samastipur, Bihar, India.

Salam P K, Rajput R S, Mishra P K, Anita and Shrivastava G K (2004) Effect of micronutrients fertilization on productivity potential of urdbean. Ann Agric 
Res25:329-32.

Salih, H.O. 2013. Effect of Foliar Fertilization of $\mathrm{Fe}, \mathrm{B}$ and $\mathrm{Zn}$ on nutrient concentration and seed protein of Cowpea (Vigna unguiculata). Journal of Agriculture and Veterinary Science, 6(3): 42-46.

Satodiya, B.N., Patel H.C., Patel A.D., Saiyad M.Y. and Leua H.N. 2011 Effect of dicapitations and PGR's on seed yield and it's attributes in clusterbean. The Asian Journal of Horticulture, 6: 38-40.

Sharma, S. K.; Chaudhary, R. P. and Dahama, A. K. 2002. Effect of phosphorous and thiourea on yield attributes and yield of pigeonpea. In: Proceedings of second International Agronomy Congress on Balancing Food and Environmental Security: A Continuing Challenges, Indian S. Agron. Indian Agril. Res. Inst. New Delhi. pp. 266-268.

Shekhawat, B.S., Shekhawat, R.P.S., and Chouhan, R.P.S. 2003. Effect of thiourea application on productivity of mothbean [Vigna acontifolia]. Indian Journal of Agriculture Science 73 (5): 294-295.

Singh, R.P. and Dasharath Singh. 2017. Response of Lentil to Thiourea Application under Rain Fed Conditions of Central India. Int.J.Curr.Microbiol. App.Sci. 6(3): 2556-2560.

Thapu U, Rai P, Suresh C and Pal P (2003)
Effect of micronutrients on the growth and yield of pea in gangetic alluvial of West Bengal. Environ Ecol21:179-82.

Togay N, Togay Y, Erman M and Cig F (2015) Effect of Fe (iron) and Mo (molybdenum) application on the yield and yield parameters of lentil (Lens culinaris Medic.) Legume Res 38:358-62.

Trivedi, A. K., Hemantaranjan, A. and Pandey, S. K. 2011. Iron application may improve growth and yield of soybean. Indian Journal of plant Physiology, 16(34): 309313.

Yadav P S, Kameriya P R and Rathore S (2002) Effect of $\mathrm{P}$ and $\mathrm{Fe}$ fertilization on yield, content and nutrient uptake in mungbean on loamy sand soil. J Indian Soc Soil Sci 50:225-26.

Yadav, B. D.; Joon, R. K. and Rana, D. S. 2003. Effect of thiourea on cowpea (Vigna sinensis L.) productivity under rainfed conditions. Advanced Arid Leg. Res. In: Indian Arid Legume Society, Scientific Publishers (India), Jodhpur. Pp.239-241.

Yadav, P.K., Sahu, M.P. and Rathore, P.S. 2006. Response of thiourea and dimethyl sulfoxide on clusterbean. Haryana Journal of Horticultural Sciences, 35: 370.

\section{How to cite this article:}

Pavan Ganesh, Vikram Singh, Dhananjay Tiwari and Dhanush Reddy. 2020. Studies on Growth, Yield and Economics of Lentil (Lens culinaris Medikus) var. IPL 316 as Influenced by Bioregulator and Micro Nutrient. Int.J.Curr.Microbiol.App.Sci. 9(12): 437-445. doi: https://doi.org/10.20546/ijcmas.2020.912.054 